\title{
Kathrin Fehringer \\ Techniques of the Body and Storytelling: From Marcel Mauss to César Aira
}

\author{
Indeed, Mauss's famous lecture is indispensable \\ for an expanded understanding of cultural techniques. \\ Geoffrey Winthrop-Young (2013) ${ }^{1}$
}

\section{1 “Excusez-moi si je vous raconte" (“Les Techniques du Corps,” 1934)}

To speak of cultural techniques means to speak of techniques of the body: it has almost become a reflex to refer to Marcel Mauss's lecture "Les Techniques du Corps" (1934) when it comes to determining what cultural techniques can be. "Les Techniques du Corps" has been widely summarized and more closely considered, yet almost exclusively in the context of (German) media studies. ${ }^{2}$ Hence it's also hardly surprising that the most popular - in the literal sense of the word passage $^{3}$ from "Les Techniques du Corps" is the often-quoted anecdote about the cinema that Erhard Schüttpelz, in his essay "Körpertechniken” (2010), reads as a

1 Geoffrey Winthrop-Young, "Cultural Techniques: Preliminary Remarks," Theory Culture \& Society 30, 6 (2013): 3-19, here 10.

2 Lorenz Engell and Bernhard Siegert, "Editorial: Kulturtechnik," Zeitschrift für Medien- und Kulturforschung 1, 1 (2010): Kulturtechnik: 5-9; Harun Maye, “Was ist eine Kulturtechnik?” Zeitschrift für Medien- und Kulturforschung 1, 1 (2010): Kulturtechnik: 121-135; Erhard Schüttpelz, "Die medienanthropologische Kehre der Kulturtechniken," in Archiv für Mediengeschichte 6 (2006): Kulturgeschichte als Mediengeschichte (oder vice versa?): 87-110; E.S., "Körpertechniken," Zeitschrift für Medien- und Kulturforschung 1, 1 (2010): Kulturtechnik: 101-120; Geoffrey Winthrop-Young, "Cultural Techniques: Preliminary Remarks," Theory Culture \& Society 30, 6 (2013): 3-19. Another classic reference text on the topic of cultural techniques alludes to Mauss's "Techniques du Corps" without, however, explicitly naming them or citing them as a source: Sybille Krämer and Horst Bredekamp, "Kultur, Technik, Kulturtechnik: Wider die Diskursivierung der Kultur," in Bild - Schrift - Zahl, ed. S.K. and H.B. (Munich: Fink, 2003), 11-22.

3 Namely, in the words of François de Pitaval, "celèbre et intéressant": "famous and interesting - famous, because [it is] interesting," as Nicolas Pethes defines "popular." See Nicolas Pethes, "Vom Einzelfall zur Menschheit: Die Fallgeschichte als Medium der Wissenspopulari-

Translated by Michael Thomas Taylor 
prerequisite for Mauss's discovery of techniques of the body (and which leads to Schüttpelz's diagnosis that "techniques of the body are media”). ${ }^{4}$ Mauss tells his anecdote as follows:

Une sorte de rélévation me vint à l'hôpital. J'étais malade à New York. Je me demandais où j'avais déjà vu des demoiselles marchant comme mes infirmières. J'avais le temps d'y réfléchir. Je trouvai enfin que c'était au cinéma. Revenu en France, je remarquai, surtout à Paris, la fréquence de cette démarche ; les jeunes filles étaient Françaises et elles marchaient aussi de cette façon. En fait, les modes de marche américaine, grâce au cinéma, commençaient à arriver chez nous. C'était une idée que je pouvais généraliser.

(“Les Techniques du Corps,” 368)

A kind of revelation came to me in hospital. I was ill in New York. I wondered where previously I had seen girls walking as my nurses walked. I had the time to think about it. At last I realised that it was at the cinema. Returning to France, I noticed how common this gait was, especially in Paris; the girls were French and they too were walking in this way. In fact, American walking fashions had begun to arrive over here, thanks to the cinema. This was an idea I could generalise.

("Techniques of the Body," 72)

Up to now, mentioning techniques of the body (and especially of Schüttpelz's essay with the same title) seems to automatically trigger a discussion in the terms of media studies. But this is currently hindering any other fundamentally different view of Mauss's lecture. ${ }^{6}$ I would thus like to separate the discussion from arguments made in the context of media studies by examining "Les Techniques du Corps" in a different way: What new findings might result from reading the text from the perspective of literary studies? ${ }^{7}$ Two problems need to be pursued more closely:

sierung zwischen Recht, Medizin und Literatur," in Popularisierung und Popularität, ed. Gereon Blaseo et al. (Cologne: DuMont, 2005), 63-92, here 63.

4 Schüttpelz, "Körpertechniken," 114.

5 Marcel Mauss, "Les Techniques du Corps," in M.M., Sociologie et Anthropologie, introduction by Claude Lévi-Strauss (Paris: Presses Universitaires de France, 1985 [1950]), 365-388. Cited hereafter as TdC. Translated as "Techniques of the Body" by Ben Brewster, Economy and Society 2, 1 (1973): 70-88. Cited hereafter as ToB. In the following I will refer to both the original French text and the English translation when details are crucial.

6 Schüttpelz himself pointed to what he saw as a kind of dud effect with Techniques $d u$ Corps: "Something appears to be hindering the concept of techniques of the body - not in its effect, but in its development”; Schüttpelz, “Körpertechniken,” 108.

7 To date, there have been no considerations of "Les Techniques du Corps" from a literarycritical perspective. The most recent study stems, once again, from the field of media studies: a twenty-page chapter titled "Körpertechniken: Rhythmen von Mensch und Maschine," in Timo Kaerlein, Smartphones als digitale Nahkörpertechnologien: Zur Kybernetisierung des Alltags (Bielefeld: transcript, 2018), 175-196. 
First, it should be noted that until now, Marcel Mauss's lecture has been read unquestioningly as a text, despite the fact that it consistently exhibits its orality. In addition to addressing his audience a number of times, Mauss even analyzes the scene of his own speaking as an example of the symbolics of techniques of the body:

Je suis en conférencier avec vous; vous le voyez à ma posture assise et à ma voix, et vous m'écoutez assis et en silence. Nous avons un ensemble d'attitudes permises ou non, naturelles ou non.

(TdC 372)

I am a lecturer for you [literally: I am with you as a lecturer]; you can tell [see] it from my sitting posture and my voice, and you are listening to me seated and in silence. We have a set of permissible or impermissible, natural or unnatural attitudes.

(ToB 76)

Mauss's lecture, as a recounting of privately experienced events (as in the anecdote about the cinema) is not only a public act of constituting meaning. Rather, it opens up public space for a collective scholarly practice when Mauss, as he himself emphasizes, is seen and heard by the scholars of the Sociéte de Psychologie to whom he is speaking. ${ }^{8}$ Such a space is opened up textually, too, when Mauss's lecture is printed in 1935 in a scholarly journal and reprinted in 1950 in an edited volume (an issue to which I will return later).

Second, the question arises regarding just which occasions for stories (that are obviously components of a scholarly practice), exactly, one is dealing with in "Les Techniques du Corps.” The question regarding the status of what I would like to call storytelling in the following has already been raised in discussions in media studies, namely in connection with the terms exemple and anecdote that Mauss himself uses. These terms have been dismissed as rhetorical ornaments, as elements of an entertaining and charming style of presentation, while also being labeled with keywords that are highly interesting from the perspective of literary studies, and which are worth examining more closely: a list, an inventor's story, report to an academy.

What Harun Maye aptly observed in writing about the "list of examples" in "Les Techniques du Corps" is that occasions for storytelling can be systematically ${ }^{10}$ sought out and also found in the text, analogous to Mauss's own dogma "example and order, that's the principle" (TdC 384; ToB 85). ${ }^{11}$ For these things

8 This could be pursued further with Hannah Arendt, Vita active oder Vom tätigen Leben (Munich: Piper, 2002); The Human Condition (Chicago: University Press of Chicago, 1958).

9 Harun Maye, "Was ist eine Kulturtechnik," 122.

10 This could be followed further elsewhere; see Jack Goody, "What's in a list?" in Goody: The Domestication of the Savage Mind (Cambridge and New York: Cambridge University Press, 1977), 338-395.

11 For this reason, the anecdote as an object of literary studies will not be the main focus of what follows. 
function as analytical instruments of innovative research, namely of that "descriptive ethnology" (TdC 365; ToB 70) initially identified by Mauss, which he not only opposes to but places above the theoretical sciences. ${ }^{12}$ This is innovative inasmuch as Marcel Mauss is considered not only the founder of French ethnology but also the inventor of social and cultural anthropology.

In situating "Les Techniques du Corps" in the interdisciplinary context of their emergence and the rhetoric on which they are based, I am thus also responding in what follows to the label of the "funny inventor's story" ("possierliche Erfindergeschichte”) that Erhardt Schüttpelz applied to Mauss's lecture, and under which "Les Techniques du Corps" has been consistently taken up in research into cultural techniques. ${ }^{13}$

To put it more precisely, it [Marcel Mauss's "successful inventor's report"] is a travesty and parody of an inventor's report, a report to an academy in the sense of Kafka, a series of variety numbers for mutual amusement. This striking textual arrangement comes from Marcel Mauss's social anthropology ...: According to Mauss, if one study's techniques of the body by studying one's own body, one encounters trained animals, and one encounters the first trained animal, the human being. ${ }^{14}$

It is from Mauss's use of the word dressage to describe techniques of the body that Schüttpelz here derives his thesis of a striking textual arrangement, the narrative use of which he describes as variety numbers: he compares Mauss's lecture with the fictional lecture setting in Kafka's story (written in 1917), in which a firstperson narrator who had appeared "on the great variety stages of the civilized world" reports to the "Gentlemen, esteemed academicians!" about his previous "apedom."15

I do not think that Mauss's language bears such Kafkaesque, "apish” traits, something to be described as the travesty of an inventor's report; Schüttpelz himself here identifies the scientific, anthropological argument that Mauss has in mind with his numerous examples and anecdotes. Mauss's language follows a logic of vividly comparing the body with a machine, on the one hand, and a trained animal, on the other, but not of equating them (French: dresser, "to train”;

12 "I recognize the higher certainty of the descriptive sciences compared to the theoretical sciences (in the case of very complex phenomena) even when I practice a theoretical science." Mauss cited from Stephan Moebius, Marcel Mauss (Konstanz: UVK, 2006), 9.

13 Schüttpelz, "Körpertechniken," 103.

14 Schüttpelz, "Körpertechniken,” 105-106.

15 Franz Kafka, "A Report to an Academy," in F.K., Metaphormosis and Other Stories, trans. Michael Hofmann (London: Penguin, 2007), 225-236, here 225. 
“to set up"; “to erect”; TdC 375). ${ }^{16}$ "Les Techniques du Corps” is therefore precisely not a Kafkaesque report; nor is it basically "funny," since Mauss relies on narrative as a scientific instrument of analysis.

Hence, in my opinion, the relating of examples and anecdotes in "Les Techniques du Corps" must also be distinguished from an elocutio (ornatus) in the sense of the general stylistic and rhetorical shaping of speech. Rather, it is a form of storytelling, namely a way of representing one (or more) occurrences. Storytelling is the act that generates an oral (or written) discourse that tells of such an event - for example, an epiphanic moment in a New York hospital. ${ }^{17}$

The aim of what follows is to analyze this storytelling and these discourses. In the sense of discovering what already exists, I understand storytelling in "Les Techniques du Corps" to be fundamentally part of an inventio of greater significance, which is bound to a scientific practice that I will trace, as it were.

Marcel Mauss himself had a love for language and its sciences. "To be a good sociologist," the 26-year old wrote in 1898, “one must be a good philologist." The study of comparative philology was a prerequisite for Mauss's interdisciplinary research interests, ensuring that he regularly read texts in the Greek or Hebrew original, in the way of a humanistic scholar. ${ }^{18}$ Hence his lecture of 1934 begins with a commentary on his own serial narration and a related gesture of apology.

16 The passage reads as follows: "Les techniques du corps peuvent se classer par rapport à leur rendement, par rapport aux résultats de dressage. Le dressage, comme le montage d'une machine, est la recherche, l'acquisition d'un rendement. Ici c'est un rendement humain. Ces techniques sont donc les normes humaines du dressage humain. Ces procédés que nous appliquons aux animaux, les hommes se les sont volontairement appliqués à eux-mêmes et à leurs enfants. ... Le pourrais par conséquent les comparer [les techniques] dans une certaine mesure, elles-mêmes et leur transmission, à des dressages, les ranger par ordre d'efficacité" TdC 374-375 (my emphasis); "The techniques of the body can be classified according to their efficiency, i.e. according to the results of training [résultats de dressage]. Training [le dressage], like the assembly [le montage] of a machine, is the search for, the acquisition of an efficiency. Here it is a human efficiency. These techniques are thus human norms of human training [dressage humain]. These procedures that we apply to animals men voluntarily apply to themselves and to their children. ... As a result I could to a certain extent compare these techniques, them and their transmission, to training systems [à des dressages], and rank them in the order of their effectivenes" (ToB 77-78; my emphasis).

17 For an introduction, see Matias Martinez and Michael Scheffel, Einführung in die Erzähltheorie (Munich: Beck, 2005 [1999], sixth edition), here 29-30, and Albrecht Koschorke, Wahrheit und Erfindung: Grundzüge einer Allgemeinen Erzähltheorie (Frankfurt am Main: Fischer, 2012); additionally, see the relevant works on narration and narrating by Gérard Genette.

18 Mauss quoted from Moebius, Marcel Mauss, 112-114. Mauss's humanistic and philosophical education, which provided him mastery of more than a dozen dead and living languages (including ancient Greek and Sanskrit), founded his reputation among students: "Mauss sait tout!" ("Mauss knows everything!"); Moebius, Marcel Mauss, 7. 
Both have probably gone unnoticed up till now because the translation into German is inaccurate: the French raconter means "to tell (stories)," but it has evidently always been understood in the sense of rapporter ("to tell" as in "to report”), which is how it has been translated into English and German.

Excusez-moi si, pour former devant vous cette notion de techniques du corps, je vous raconte à quelles occasions j'ai pu poser clairement le problème général. Ce fut une série de démarches consciemment et inconsciemment faites.

(TdC 366; my emphasis)

Forgive me if, in order to give this notion of techniques of the body shape for you, $\underline{I}$ tell you about the occasions on which I pursued this general problem and how I managed to pose it clearly. It was a series of steps consciously and unconsciously taken.

(ToB 71)

At the same time, Mauss speaks of a chain of insights connected with a series of personally experienced events that he subsequently narrates (sometimes in more detail, and sometimes less) and analytically sets forth as a "series" of conscious and unconscious steps of thought. In this regard, Mauss's lecture (which was presumably read aloud) could thus be described as a kind of autohistoriography of his own scientific practice, which produced a new discipline, clarifying Schüttpelz's label of an “inventor's report," the subject of which is often Marcel Mauss's own body.

In connection with the term raconter, Mauss himself uses the terms exemple and décrire ("example/to describe") or anecdote and raconter ("anecdote/to tell stories”) as synonyms, or he merges or overlaps them in his usage:

Je dis bien les techniques du corps parce qu'on peut faire la théorie de la technique du corps à partir d'une étude, d'une exposition, d'une description pure et simple des techniques du corps. J'entends par ce mot les façons dont les hommes, société par société, d'une façon traditionelle, savent se servir de leur corps. En tous cas, il faut précéder du concret à l'abstrait, et non pas inversement. / Je veux vous faire part de ce que je crois être une des parties de mon enseignement qui ne se retrouve pas ailleurs, que je répète dans un cours d'Ethnologie descriptive ... / ... Excusez-moi si, pour former devant vous cette notion de technique du corps, je vous raconte à quelles occasions j'ai poursuivi et comment j'ai pu poser clairement le problème général. Ce fut une série de démarches consciemment et inconsciemment faites.

(TdC 365-366; italics in the original; my emphasis underlining)

I deliberately say techniques of the body in the plural because it is possible to produce a theory of the technique of the body in the singular on the basis of a study, an exposition, a description pure and simple of techniques of the body in the plural. By this expression I mean the ways in which from society to society men know how to use their bodies. In any case, it is essential to move from the concrete to the abstract and not the other way round. / I want to convey to you what I believe is one of the parts of my teaching which is not to be found elsewhere, that I have rehearsed in a course of lectures on descriptive ethnology ... / Forgive me if, in order to give this notion of techniques of the body shape for you, $\underline{\text { I tell you }}$ about the occasions on which I pursued this general problem and how I managed to pose it clearly. It was a series of steps consciously and unconsciously taken.

(ToB 70-71) 
The numerous concret facts function as case studies and thus as constitutive components of an inventio in the sense of a discovery of arguments, designed as an experiment: On the one hand, the piling up of the exemples and anecdotes represents a problem-solving strategy, or method, that still takes place in narration, and which is therefore processual and investigative. And on the other hand, these reported and narrated case studies serve as supporting evidence for the solutions already discovered, which Mauss provides as concise definitions; one of these sentences here forms the prelude to the lecture and has in the meantime become a commonplace in research into cultural techniques ("By this expression I mean the ways in which from society to society men know how to use their bodies").

In this context, I would like to propose that "Les Techniques du Corps" be understood as a popular case history, a text genre that has, in recent years, become a focus of work in literary studies. Case histories are characterized by the fact that they constitutively depend on storytelling (and thereby take recourse to other stories) to describe phenomena whose observation precedes the creation and institutionalization of new scientific disciplines. ${ }^{19}$ This is true, for example, of the development of modern psychology (in the eighteenth and nineteenth centuries) and, with Mauss, obviously for the emergence of the new disciplines of ethnology and anthropology following the First World War.

However, the concept of case history not only provides a central view of the role of narrative in Mauss's "inventor's story." In particular, it also enables a retrospective view of the individual case - largely lacking in current debates about cultural technologies, and the express concern of this volume - that Mauss takes to be the foundation for any theory; and from here, it enables an innovative view of literary texts. This is why I will finally turn, with Mauss, toward a literary text that stages techniques of the body as bodily injury and, by doing so, to the primary cultural techniques of drawing and writing: Un episodio en la vida del pintor viajero ("An Episode in the Life of the Traveling Painter") by the Argentine writer César Aira (2000). ${ }^{20}$

The novel, which claims to be an episode in its title, is a case history insofar as it relates to a serious riding accident and its consequences. It takes place in the emptiness of the Argentine pampas, which motivated the painter and geographer

19 For an exemplary treatment of this topic, see Nicolas Pethes, "Vom Einzelfall zur Menschheit,” in Das Beispiel: Epistemologie des Exemplarischen, ed. N.P., Jens Ruchatz, and Stefan Willer (Berlin: Kadmos, 2007).

20 César Aira, Un episodio en la vida del pintor viajero (Mexico City: Era, 2001; first edition 2000 by Rosario, Buenos Aires, Argentina), translated by Chris Andrews as An Episode in the Life of a Landscape Painter, in Three Novels by César Aira, preface by Roberto Bolaño (London: Penguin, 2015; 141-230). 
Moritz Rugendas to set out on a mission of scientific documentation and exploration during the 1830s, prompted by Alexander von Humboldt. The novel is structured as a fictionalization of private letters written by Rugendas, who did in fact live in Augsburg.

The text is amenable to description with classical methodological categorizations and concepts from literary studies (for example, the notion of écriture automatique) and is therefore well suited for making visible the interdisciplinary possibilities of a perspective concerned with cultural techniques. My aim is to make clear how a perspective concerned with (cultural) techniques of the body can, as a method, enrich literary analysis. Conversely, I would like to try to show that, and to what extent, literatures can partake in determining techniques of the body and hence cultural techniques.

This will bring me back to the discussion in media studies, namely, to one of the great, controversial and unresolved questions of current research into cultural techniques: whether "techniques of the body can be subsumed under cultural techniques or, conversely, cultural techniques can be derived from the techniques of the body," as Harun Maye puts it. ${ }^{21}$ By considering Mauss's speech and Aira's text, this question can also be posed in a different way.

\section{Backgrounds: Textual Space and Interdisciplinarity}

Mauss gave his lecture on May 17, 1934, to the Société de Psychologie in Paris, an association of worldwide importance founded by Pierre Janet in 1901 that Mauss himself chaired in 1924. As part of his efforts to expand and scientifically consolidate the school of his uncle and teacher Émile Durkheim after the First World War, Mauss initiated a new dialogue between sociology and psychology. ${ }^{22}$ In his lecture he explicitly addresses the research positions of some psychologists, such as George Dumas (TdC 369; ToB 73), the former chairman of the Société de Psychologie and co-editor of its periodical, in which Mauss's speech also appeared.

In his lecture, Mauss advances the strong thesis that there are no natural postures (TdC 368; ToB 72) or modes of action (TdC 371; ToB 75) of the body: He argues these were all "not simply a product of some purely individual, almost completely

21 Maye, “Was ist eine Kulturtechnik,” 122.

22 This went hand in hand with the development of ethnology; see Moebius, Marcel Mauss, 9. Durkheim's exclusion of psychology is thus expressly undone by Mauss (see 92). On the consultation of the Durkheim School, see 51-64. 
psychical arrangements and mechanisms" (TdC 368; ToB 72) but rather social and learned. The same applied to perception, he argues, which he sees as equally socially conditioned, and evidently also to the representations of the trained body, as Mauss shows with the example of the imitation of fashionable gaits that his nurses copied from cinema actresses. ${ }^{23}$

Mauss claims he needed considerations from three disciplines ("triple viewpoint," TdC 369; ToB 73) - sociology, psychology, and biology - to develop his method, namely "the ways in which from society to society men know how to use their bodies" (TdC 365; ToB 70) to make the body something that can be described and systematized. He argues that the social element (habitus, "collective and individual practical reason," TdC 369; ToB 73) and with it the question of education, fashions, and prestige, were of primary significance for the development of techniques of the body. In second place, however, he places the psychological element ("psychological momentum," TdC 371; ToB 75, which he examines using the example of magical action, formulae, and objects) and the anatomicalphysiological element (overcoming “biological resistance,” TdC 371; ToB 75, using examples of words and magical objects), in which imitation and talent or faculty played a major role (TdC 369; ToB 73).

In a culmination of his argument, Mauss follows by speaking of "elements of the art of using the human body" (TdC 369; ToB 73; my emphasis) and thus no longer of "ways." He finally grasps this art of acting by using the concept of technology as individual and collective habits (habitus) stemming from "practical reason." 24 Mauss understands this art of using the body in the ancient Greek sense as techné, i.e., in the sense of an embodied practical knowledge of how to approach and execute something.

In emphasizing their theorization as a "série d'actes montées" ("series of assembled actions"; TdC 372; ToB 76), i.e.: as a chain of operations, these techniques of the body themselves recall their own proven method of analysis as "a series of steps consciously and unconsciously taken.”

23 Hence "Les Techniques du Corps" is among the first contributions of a sociology (if not a pre-Foucauldian archaeology) of the body; see Moebius, Marcel Mauss, 77. It is the body as a "social formation" that first guides how Mauss perceives our body as a "physical formation," as the social anthropologist Mary Douglas wrote about Mauss in 1970. Mary Douglas, Natural Symbols: Explorations in Cosmology (London: Routledge, 1996 [1970]). On the summary of "Les Techniques du Corps" and their classification in Mauss's thinking, see Moebius, Marcel Mauss, 77-78 and 105.

24 Already in 1901, Mauss specified these collective habits as the proper central object of sociological research, which he understood as "intersections of social practices that vary according to society and tradition and can change over time." In "Les Techniques du Corps" he chooses the Latin term habitus to describe these practices; see Moebius, Marcel Mauss, 77. 
As a text, although quite obviously unchanged in its original orality, Mauss's lecture appeared one year later in 1935 in the periodical of the Société de Psychologie (Society of Psychology), the Journal de Psychologie Normale et Pathologique ("Journal of normal and pathological psychology"), published from 1904 to 1915 and 1920 to 1940 (i.e. pausing during the First World War, and until the beginning of World War II). This journal usually refers to the minutes of the Société meetings held several times a year, while also printing the lectures given at these meetings. The Société de Psychologie always only forms a subschapter in the journal's structure. Above all, it offered a platform for new, interdisciplinary approaches to research, including from cultural philosophy. ${ }^{25}$ One special volume Psychologie du Language ("Psychology of language," 1933), for instance, lists texts by Karl Bühler and Ernst Cassirer in its section on "language theory."26

"Les Techniques du Corps" are therefore also located textually in an interdisciplinary context - here, between existing disciplines; this makes it possible to recognize the discursive effort with which Mauss tries to link his theses to the scholarly horizon of an event that is mainly attended by psychologists. In understanding Mauss's lecture as a case history, however, I advocate for the strong thesis of locating it on the border of unexplored realms, namely, the creation of a new scholarly discipline, ethnology and ethnography ("Ethnologie descriptive").

In 1950, the year of Mauss's death, an anthology is published in his honor in which "Les Techniques du Corps" is printed for the second time, and which literally bears the signature of the book's ethnological approach, even if it is not reflected in the book's title: Sociologie et Anthropologie ("Sociology and Anthropology”): A foreword by Claude Lévi-Strauss, the last pupil of Mauss (and an ethnologist) is intended to help the volume - and thus Mauss's research - reach a larger, international audience and hence to fulfill a desideratum of sociologists and ethnographers, as well as students of these disciplines who had until then been obliged to go looking for his texts with great effort (TdC VII). ${ }^{27}$ In this anthology of seven texts, containing first and foremost

25 Marcel Mauss, "Les Techniques du Corps," Journal de Psychologie Normale et Pathologique 32, ed. Pierre Janet and George Dumas (Paris: Presses Universitaires de Paris, 1935): 271-293. https://gallica.bnf.fr/ark:/12148/bpt6k9656899d/f7.item (visited on May 22, 2019).

26 Ernst Cassirer, "Le langage et la construction du monde des objets," and Karl Bühler, "L'onomatopée et la fonction représentative du language," Journal de Psychologie Normale et Pathologique 33 (1933): Psychologie du Langage: 8-44 and 101-119.

27 The introduction by Lévi-Strauss to the work of Marcel Mauss was so famous and controversial that it had a considerable influence on the reception of Mauss as an "ingenious, yet ultimately unsystematic predecessor of structuralism.” See Stephan Moebius and Frithjof Nungesser, "La réception de Mauss en langue allemande," Trivium: Revue franco-allemande de sciences 
the "Théorie générale de la magie" ("general theory of magic") and the famous "Essai sur le don" ("essay on the gift”), "Les Techniques du Corps" occupies the sixth place.

"Les Techniques du Corps" is a by-product of his lectures in the context of his institutionally founded "descriptive ethnology" to which he explicitly refers at the beginning of his lecture (TdC 365; ToB 70). ${ }^{28}$ Mauss had founded the Institut d'Éthnologie de l'Université de Paris (Institute of Ethnology of the University of Paris) with an École Pratique (or practical school) in 1925, which, at the time of his speech, had already been extremely successful for ten years in training medical doctors, colonial officials, missionaries, and ethnographers. ${ }^{29}$

In his home country, Marcel Mauss exerted an enormous influence on the humanities. Throughout his life, he worked to ensure cooperation between disciplines. ${ }^{30}$ This might be the reason why "Les Techniques du Corps" is so convincing as a key text in current discussions about cultural techniques. Lévi-Strauss' foreword has ensured that Mauss is perceived as a highly gifted man who ${ }^{31}$ "gets bogged down in a thousand details," as René König, one of the first German Mauss specialists, critically writes, which is why König also called in 1978 for Mauss's “detailed analyses" to be valued as "particularly instructive."32

Scholars repeatedly refer to the fragmentary character of Mauss's works (including the "Techniques du Corps"), which Mauss himself titled "essays," "drafts," or "sketches." 33 His ideal is to work in fragmentary forms and comes from his declared research interest in wanting to examine and understand "l'homme total," "the "total man"” (TdC 369; ToB 73). In this sense, there is no

humaines et sociales 17 (2014): 1-9, here 5-6. https://journals.openedition.org/trivium/4828 (visited on March 25, 2019). On this point, see also Moebius, Marcel Mauss, 130-131.

28 "I want to convey to you what I believe is one of the parts of my teaching which is not to be found elsewhere, that I have rehearsed in a course of lectures on descriptive ethnology" (TdC 365; ToB 70).

29 Yet, Mauss was himself never a traveler; see Moebius, Marcel Mauss, 9-10.

30 As the first holder of a chair of social sciences in France, Durkheim founded the journal L'Annee sociologique, which served as a kind of laboratory for interdisciplinary collaboration in the service of Durkheim's and Mauss's ideal of collective collaboration. On this point, see also Moebius, Marcel Mauss, especially 43-47.

31 Claude Lévi-Strauss, "Introduction à l'Euvre de Marcel Mauss," in Sociologie et Anthropologie, ed. C.L.-S. (Paris: Presses Universitaires de France, 1950), IX-LII; see also Moebius, Marcel Mauss, 129-136.

32 René König quoted from Moebius, Marcel Mauss, 129; on René König as researcher who worked on Mauss since the 1930s, see Moebius and Nungesser, "La réception de Mauss en langue allemande."

33 Moebius, Marcel Mauss, 129. 
"pure” discipline for Mauss. The fragmentary character of his works reflects an understanding of research, as Mauss explains, prefacing his remarks ${ }^{34}$ :

En tous cas, il faut procéder du concret à l'abstrait, et non pas inversement./ ... Or, l'inconnu se trouve aux frontières des sciences là où les professeurs "se mangent entre eux," comme dit Goethe (je dis mange, mais Goethe n'est pas si poli). ... Il y a toujours un moment où la science de certains faits n'étant pas encore réduite en concepts, ces faits n'étant pas même groupés organiquement, on plante sur ces masses de faits le jalon d'ignorance: "Divers". C'est là qu'il faut pénétrer.

(TdC 365)

In any case, it is essential to move from the concrete to the abstract and not the other way round. ... Now the unknown is found at the frontiers of the sciences, where the professors are at each other's throats, as Goethe put it (though Goethe was not so polite). ... There is always a moment when, the science of certain facts not being yet reduced into concepts, the facts not even being organically grouped together, these masses of facts receive that posting of ignorance: "Miscellaneous." This is where we have to penetrate.

(ToB 70)

Mauss's selection of faits divers, or "miscellaneous," ${ }^{35}$ represents the nucleus of his storytelling. At the boundary of research where Mauss quotes Goethe with a wink, while actually marking the emergence of a new scholarly discipline, Mauss establishes himself as a observateur ("narrating observer”): Mauss's method of "Ethnologie descriptive" (TdC 365; ToB 70) requires (initially) taking recourse to storytelling. For instance, the scholarly and thus factual speech intended to serve description ("descriptive") is in fact a more or less adventurous, narrative quest for knowledge (What are techniques of the body?) and its order (How are techniques of the body to be systematized?). They are adventurous to the extent that the numerous, often extremely personal exemples and anecdotes tell especially of Mauss's time as a soldier in the First World War and amateur athlete (swimming, mountaineering, boxing); they tell, for example, of sleeping on piles of stones in the field or on a ledge overlooking an abyss in the mountains, and in doing so they testify to a desire for (serial) storytelling that, from the perspective of literary studies, is worth taking seriously despite, or precisely because, of its entertainment value.

34 He thus also describes the approach of a current interest of research into cultural techniques that this volume would like to represent, and that revolves around working on concrete materials in defining the concept of "cultural techniques."

35 The French expression "fait divers" refers to a marginal newspaper article. Such an article, for instance, respectively served nineteenth-century authors Gustave Flaubert and Theodor Fontane, to give two examples, as the nucleus for their novels Madame Bovary and Effi Briest. See also Roland Barthes, "Structure du fait divers," in R.B., Euvres complètes, vol. 1 (Paris: Seuil, 1995), 1306-1319, and Nicolas Pethes' essay in this volume. 
I therefore propose understanding "Les Techniques du Corps" as an autohistoriographic case history: case histories (from the Latin casus, a medical or legal case) are inevitably disciplinary because they precede the development of new disciplines; they are characterized by narrative modes that elevate empirical observations to a narrative principle. To describe Mauss's use of storytelling at the boundary of a new discipline - and of what is perhaps an equally novel narrative strategy that transforms itself, in its serial character, to become like its object (and not, for example, the other way around) - one could argue, following Nicolas Pethes, that Mauss's attempt at such a survey of a new field of knowledge shows that, "as a case history ... ["Les Techniques du Corps"] is not a subsequent or secondary addition to a theorem that is already known as such but rather the sole illustrative material for its justification." ${ }^{36}$

\section{Mauss's Body: Occasions for Storytelling}

The wit of Mauss's lecture lies above all in the fact that Mauss presents himself as his own casus. The seriousness required to appear before a scholarly audience is ensured by the great temporal distance to his youthful self, which the speaker by then as aged as he was famous - regards with a certain self-irony. This is probably why Erhard Schüttpelz describes Mauss's "inventor's story" as "funny," speaking of "variety numbers for mutual amusement." Thus, we might expect that Mauss's language would generate a popularizing effect, possibly resulting from its proximity to the historical genre of case history.

Case histories do not serve to "popularize already existing knowledge but [are] rather a popular medium within an [existing] scientific system, which is always accessed when it is necessary to measure new fields of knowledge." ${ }^{37}$ Casuistic modes of storytelling do not draw from the "inventory" of "literature and science [Wissenschaft]" but constitute this inventory in the first place. ${ }^{38}$ Case histories deal with exemplary cases, which are to be understood as exemplary narratives, and which both document and enable comparisons. As with Mauss, they seek out "the relationship between individual observation and general law."39

36 Pethes, "Vom Einzelfall zur Menschheit," 75.

37 Pethes, "Vom Einzelfall zur Menschheit," 73.

38 Pethes, "Vom Einzelfall zur Menschheit," 78. Pethes' arguments concern texts from the late eighteenth century from the field of early psychology.

39 Pethes, "Vom Einzelfall zur Menschheit," 69-71. 
Such an approach can already be observed structurally in "Les Techniques du Corps," in which the narrative part takes up about a quarter of the lecture, because Mauss argues in four steps (I-IV) in order to move from the individual case to the theory or abstract, which is then tested once again in its application to the individual case. His lecture thus follows a systematic procedure, the key words of which Mauss himself names: raconter (I, "to tell stories"), énumérer (II, III, “to list”), considérer généralement (IV, “to judge”).

Read in this way, the anecdote about the cinema in New York serves Mauss solely as a popular prelude to his remarks, because it remains isolated as an anecdote. Mauss draws above all from a great stock of personal memories as a soldier and young athlete (at the time of his lecture he was over sixty, during the war he was in his forties) or, as here, from his school days:

Exemple: je crois pouvoir reconnaître aussi une jeune fille qui a été élevée au couvent. Elle marche, généralement, les poings fermés. Et je me souviens encore de mon professeur de troisième m'interpellant: "Espèce d'animal, tu vas tout le temps tes grandes mains ouvertes! "Donc il existe également une éducation de la marche.

(TdC 368; my emphasis)

For example: I think I can also recognise a girl who has been raised in a convent. In general she will walk with her fists closed. And I can still remember my third-form teacher shouting at me: "Idiot [You brute] ! why do you walk around the whole time with your hands flapping wide open?” [literally: "You piece of an animal always walking with those big hands open!"] Thus there exists an education in walking, too.

(ToB 72)

Just before this passage, Mauss introduces the topic with personal memories of his swimming lessons and the First World War. He relies upon a horizon of experience that he shares with his audience - namely, scholars of his age who had served as soldiers as he did - in order to diagnose a paradigm shift in techniques of the body, using swimming as an example. He does so by comparing the human body with a machine, the steamboat. Physical techniques, as habitualized techniques, are thus seen as subject to the logic of processual stabilization and destabilisation.

[N]otre génération, ici, a assisté à un changement complet de technique: nous avons vu remplacer par les différentes sortes de crawl la nage à brasse et à tête hors de l'eau. De plus, on a perdu l'usage d'avaler de l'eau et de la cracher. Car les nageurs se considéraient, de mon temps, comme des espèces de bateaux à vapeur. C'était stupide, mais enfin je fais encore ce geste: je ne peux pas me débarrasser de ma technique.

... Dans le même temps [pendant la guerre] j'ai eu bien des occasions de m'apercevoir des différences d'une armée à l'autre. Une anecdote à propos de la marche. Vous savez tous que l'infanterie britannique marche à un pas différent du nôtre: différent de fréquence, d'une autre longueur. ... Pendant près de six mois, dans les rues de Bailleul ..., je vis souvent le spectacle suivant: le régiment avait conservé sa marche anglaise et il la rythmait à la 
française. Il avait même en tête de sa clique un petit adjudant de chasseurs à pied français qui savait faire tourner le clairon et qui sonnait les marches mieux que ses hommes. Le malheureux régiment de grands Anglais ne pouvait pas défiler. Tout était discordant de sa marche. Quand il essayait de marcher au pas, c'était la musique qui ne marquait pas le pas. Si bien que le régiment de Worcester fut obligé de supprimer ses sonneries françaises.

(TdC 366-367; italics in the original; my emphasis)

$[\mathrm{H}]$ ere our generation has witnessed a complete change in technique: we have seen the breast-stroke with the head out of the water replaced by the different sorts of crawl. Moreover, the habit of swallowing water and spitting it out again has gone. In my day swimmers thought of themselves as a kind of steam-boat. It was stupid, but in fact I still do this: I cannot get rid of my technique.

... In the same period I had many opportunities to note the differences between the various armies. An anecdote about marching. You all know that the British infantry marches with a different step from our own: with a different frequency and a different stride. ... For nearly six months, in the streets of Bailleul [provincial town near Dunkerque], long after the Battle of the Aisne, I often saw the following sight [literally: spectacle]: the regiment had preserved its English march but had set it to a French rhythm. It even had at the head of its band a little French light infantry regimental sergeant major who could blow the bugle and sound the march even better than his men. The unfortunate regiment of tall Englishmen could not march. Their gait was completely at odds. When they tried to march in step, the music would be out of step. With the result that the Worcester Regiment was forced to give up its French buglers.

(ToB 71-72)

This series of five short and detailed stories at the beginning of the lecture (well known to scholars of cultural techniques) can be taken as exemplary for numerous exemples and anecdotes in Mauss's lecture - and not (only) because they share the entertainment value that is often attributed to them. First, they outline a situation of observation; and second, they show that it is Mauss's recourse to storytelling that allows him in the first place (namely in the exposition) to speak of techniques of the body and to attempt to define them, as he himself puts it in the beginning of his lecture.

To do so, Mauss draws primarily on memories of the erudition and training of his own moving (or nonmoving) body, which is explicitly marked as a youthful or young body. With this body, Mauss presents himself as a former passionate (extreme) athlete and thus as the first experimental object in his (discursive) experiment. The examples from ethnology represent reported, foreign knowledge, playing a role in the middle part of the argumentation. ${ }^{40}$ By contrast, the biographical parts of the lecture substantiate, on the one hand, a very private and

40 Mauss himself never conducted any field research (see Moebius, Marcel Mauss, 9-10), but he did study the idiosyncrasies of various nations (such as Australia, TdC 374; ToB 77), especially during the war. It can be assumed, however, that "Les Techniques du Corps" testifies to a contemporary colonial discourse. Yet this is not easy to verify since Mauss's examples 
personal research interest and, on the other, the status of how this (discursive) experiment is set up. Mauss proves himself to be an attentive observer and a witty narrator in determining those techniques of the body that he explicitly describes as a "spectacle" at the end of the series named above.

Mauss's own passion is focused on Alpinism, which he narrates spectacularly; the series of examples he gives is found in the last part of his remarks, where it belongs to the systematic categories of enumeration and judgment, the basis of which he illustrates again using individual cases. Hence their narrative effort is extremely limited, and as a small-scale series they vividly counterbalance the narrative effort from the beginning of the lecture:

1. "J’ai dormi debout en montagne. / I have slept standing up [upright] in the mountains."

(TdC 379; ToB 81)

2. "Je peux vous dire que je suis très mauvais grimpeur à l'arbre, - passable en montagne et sur le rocher. / I can tell you that I'm very bad at climbing trees, though reasonable on mountains and rocks.”

(TdC 381; ToB 83)

3. "L'histoire des méthodes d'alpinisme est tout à fait remarquable. Elle a fait des progrès fabuleux pendant mon existence. / The history of mountaineering methods is very noteworthy [absolutely remarkable]. It has made fabulous progress in my life-time."

(TdC 381; ToB 83; my emphasis)

4. "La principale utilité que je vois à mon alpinisme d'autrefois fut cette éducation de mon sang-froid qui me permit de dormir debout sur le moindre replat au bord de l'abîme. / The main utility I see in my erstwhile mountaineering was this education of my composure [sang-froid; literally: "cold blood"], which enabled me to sleep upright on the narrowest ledge overlooking the abyss."

(TdC 385; ToB 86).

This small-scale series has its own narrative appeal: it revolves around the highly personal limit experiences that Mauss had as an extreme athlete, which - as sleeping on the edge of the abyss - provide the framing and reason for this narrative event, ultimately being hyperbolically exaggerated ("on the narrowest ledge") while being distanced from Mauss's own self ("erstwhile"). Interestingly, the series also raises the question of histories of sport. At the same time, it underpins Mauss's most important conclusion: that techniques of the body consist of an education in "sang-froid" as Mauss says.

Methodologically, "Les Techniques du Corps" is therefore particularly useful in analyzing the relationship between literature and sports, as well as for narratives of the war out of which sports emerged (both historiographically and in

in this regard extend to tribes from Australia and New Zealand (Maori) outside the French colonial area. 
Mauss's logic). ${ }^{41}$ For the storytelling occasions Mauss uses to determine techniques of the body enable us to see the very spectacle of techniques of the body that appear in literary storytelling. I believe that - especially when bodies no longer function as constants, but are hazarded in (literary) experimental arrangements - techniques of the body are not only told but reflected in their possibilities and meanings. If one follows Mauss, such experimental arrangements determine stories of (threatening) damage to the body ("I was ill in New York" as a hospital scene [my emphasis]; war situations), on the one hand, and from this perspective, narratives of (extreme) sports, on the other. For instance, Mauss does not initially speak of techniques of the body that he had observed in English and French regiments, but of "elementary [and] sporting techniques" (TdC 367; ToB 72).

César Aira's Un episodio en la vida del pintor viajero tells of such an experimental arrangement: the narration is based on the story of the Rugendas family of painters from Augsburg. The great-grandfather - with whom the novel begins as the origin of a dynasty of painters - must re-educate himself from righthandedness to left-handedness following a war injury, which also entails swapping the profession of clockmaker for that of painter. What is described in the rest of the novel is the story of a similarly injured great-grandson, the protagonist of the narrative, who enhances the inherited manual techniques in a highly modern way: transforming them into écriture automatique.

\section{Techniques of the Body and Maimed Literary Figures: César Airas Un episodio en la vida del pintor viajero (2000)}

With his cinema anecdote at the beginning of his lecture, Mauss touches, via the apparatus of film, on the question of how techniques of the body are represented. Surprisingly, he does not here establish distance from his story, as he does elsewhere. Rather, he reads the movie as proof of a "trendy" style of walking - the popularity of which ("interesting and famous," in Pethes' terms) he designates with the term “fashion” (la mode, TdC 368; ToB 72). Yet in Mauss’s Hollywood

41 This was shown by an interdisciplinary workshop on "sports and techniques of the body" held at the Universität Erfurt in the summer of 2018; on stories of war and techniques of the body, see my essay "Workaround am eigenen Leib: Das Narrativ der Prothese bei Otto Dix und in der französischen Gegenwartsliteratur,” Ilinx: Berliner Beiträge zur Kulturwissenschaft 4 (2017): 23-39. 
film, the American walking fashion ("la marche américaine") is precisely not documented but staged. In this context, a central question concerning techniques of the body and their narrative(s) is the opening and measuring of spaces. It is obvious that, as an ethnologist, Mauss also measures geographical spaces in studying techniques of the body, from the North American city to a provincial city near Dunkerque or the Australian hunting grounds where indigenous people are observed climbing trees (TdC 370; ToB 171).

The novel of the Argentinian writer César Aira, Un episodio en la vida del pintor viajero (An Episode in the Life of a Landscape Painter), deals with such a measuring of new spaces and fields of knowledge in the sense of a case history. In this text, the main character Moritz Rugendas, a painter and explorer, sketches a malón ("Indian raid") in numerous fragments of various scales and dimensions on numerous sheets of paper. At the beginning of the novel, we learn of the "traveling painter" that he invented the new painting technique of the oil sketch that anticipated Impressionists (ELP 157). ${ }^{42}$ His art was to be understood in the sense of a "science of landscape":

Rugendas fue un pintor de género. Su género fue la fisionómica de la Naturaleza, procedimiento inventado por Humboldt ..., una suerte de geografía artística, captación estética del mundo, ciencia del paisaje.

(EPV 10)

Rugendas was a genre painter. His genre was the physiognomy of nature, based on a procedure invented by Humboldt ..., a kind of artistic geography, an aesthetic understanding [literally: capturing] of the world, a science of landscape.

(ELP 147)

To carry out his method of "artistic geography" borrowed from Humboldt, the pintor viajero sets out, in the late 1830s, with a cart "of monstrous size" on the arduous crossing into the yet unsurveyed, unmeasured pampas. Along the "straight line" from Mendoza via San Luis to Buenos Aires, he covers a distance of two hundred meters per day - it would take "a lifetime" to reach the goal (ELP 164-165). ${ }^{43}$ But he ultimately manages to travel just a quarter of the distance: because a catastrophic riding accident forces him to turn back.

This accident forms the center of the "episode in the life" of Rugendas (EPV 29-35; ELP 172-179), a real historical figure who was a protégé of Alexander von Humboldt. Rugendas's travels to Latin America, such as the trip to Argentina depicted in Aria's text, are documented in numerous letters, drawings, lithographs,

42 In the following I will refer to both the Spanish original text (EPV - Episodio Pintor Viajero) and the English translation (ELP - Episode Landscape Painter) when details are crucial; "una práctica novedosa, la del boceto al óleo" (EPV 18).

43 "un artefacto de tamaño monstruoso," "línea recta," "vidas entieras" (EPV 23-24). 
and paintings. ${ }^{44}$ At its outset, the text claims to be a literary narrative but biographically accurate documentation of the "episode" from which the book takes its title, similar to how the painter set out to document the pampas. As the story unfolds, but at the latest after the riding accident that leaves Rugendas with a grave injury on his face, the narrative pace accelerates to finally depict, amid a great din of surrealistic registers, a hallucinating painter among “savages.”45

I would now like to examine Aira's Episodio as inspirationally similar to Mauss' “Les Techniques du Corps," namely as an experimental arrangement for a scientific, medical, artistic, and - on a poetological level - narrative experiment. Ultimately, I want to show to what extent cultural techniques as a method can enrich the literary view of narrative texts, namely, by not circumventing established orders and concepts such as the grotesque and écriture automatique, but by rendering them describable (in a different way, anew). Once again, the concept of (biographical) case history will help me investigate how the literary text operates, in this context, with techniques of the body, with their stagings and spectacular compressions in narrative form.

Aira's "episode" is a case history when it tells how an injury occurs, how it is treated, and how the injured person begins, under the constant influence of morphine, to ride out again, to draw sketches as a means of research - ultimately with an effort that is no longer geographical, but ethnological - ${ }^{46}$ in order to document a malón. The accident destabilizes the body and its techniques to such an extent that the painter has no choice but to accept this new normality.

In this sense, the episodio tells of the destabilization and stabilization of habitualized techniques of the body, and it therefore does not end with Rugendas's death but with finally achieving the goal of mixing among the "Indians" as one of their own in order to be able to depict them undisturbed. "This last part of the episode" (ELP 226) culminates in an anachronistic - and hence all the more grotesque - cinematic image: "In the depths of that savage night, intoxicated by drawing and opium” (ELP 230), the "monstrous painter” (ELP 227) sits at the campfire amid drunken "savages” to celebrate an earlier military campaign. ${ }^{47}$ As

44 Parts of Rugendas's work can be found in the Buenos Aires City Museum, the Augsburger Stadtarchiv, and the Staatliche Graphische Sammlung München.

45 Throughout the text, and in its historical context, Native Americans are referred to as "savages."

46 Lévi-Strauss's Tristes Tropiques (English title Tristes Tropiques, Spanish title Tristeza del Trópico, literally sad tropics) are mentioned ("tristeza del trópico"; EPV 65; translated as "tropical sadness," ELP 219). First published in France in 1955, the autobiographical text documents Lévi-Strauss's travels to the heart of Brazil between 1935 and 1938.

47 “Esta parte final del episodio” (EPV 71); „Drogado por el dibujo y el opio, en la medianoche salvaje” (EPV 74); “pintor monstruo” (EPV 72). 
the flames once again illuminate Rugendas's injury, the "Indian" faces repeat and multiply the twitching movements of his face (ELP 229) ${ }^{48}$ : The painter becomes a blinking machine.

From the outset, the reader is systematically unsettled as to whether the "episode" is, in fact, a historically certain event or whether the fait divers (concrete fact) of Rugendas's injury is fictitious. ${ }^{49}$ This unsettling is consistently heightened by language that is itself increasingly infected by the madness of the painter and his grotesque body, as the narrative of the injury and how it is dealt with first leads to the narrative of an "Indian" attack, which Rugendas sketches while riding a horse. The text entertains the reader with a wealth of exaggerations, comparisons, and metaphors, producing the impression, from the anachronistic perspective of the late 1990s in which it was written, of a complete reversal of the world through the invasion of the supposed "savage." 50

The grotesque play with semantics related to techniques of the body (such as walking and riding) and the injuries of the body and its manual techniques (such as drawing and warfare) begins with the story of a maimed painter's hand and the relearning of techniques of the body. The hand of this painter founded the Augsburg dynasty of painters to which Rugendas belongs, and thus also founds Aira's case history. The passage is reminiscent of Miguel Cervantes, a soldier who famously said about the success of his Don Quixote that he had lost the ability to move his left hand to the glory of his right. ${ }^{51}$

48 "A la luz bailarina del fuego, sus rasgos dejaban de pertenecerles. Y aunque poco a poco recuperaron cierta naturalidad, y se pusieron a hacer bromas ruidosas, las miradas volvían imantadas a Rugendas, al corazón, a la cara” (EPV 74).

49 At one point, in any case, the text expressly asserts its factuality: "haya tantos datos, no sólo de los hechos sino de sus repercusiones íntimas, respecto de todo lo que rodéo a este episodio. La documentación era el oficio de Rugendas el pintor, y en alas de la excelencia lograda se le había vuelto una segunda naturaleza a Rugendas el hombre"; "there is so much information directly or indirectly related to this episode, concerning not only the events themselves but also their intimate repercutions. The artist's mastery of documentation had carried over to the rest of his life, becoming second nature to the man" (EPV 41; ELP 187).

50 On the connection between laughter, fear, and the reversal of the world, see the centrally exemplary work of Mikhail Bakhtin, Rabelais and his World, trans. Hélène Iswolsky (Bloomington: Indiana University Press, 1984 [1968]), and, focusing on the Gothic novel, Wolfgang Kayser, The Grotesque in Art and Literature, trans. Ulrich Weisstein (New York: Columbia University Press, 1981 [1963]).

51 Cervantes writes this in the preface to his Novelas Ejemplares. He suffered a gunshot wound to his left forearm during the famous naval battle of Lepanto in 1571, which left his hand permanently paralyzed and gave him the nickname "el manco de Lepanto" (the one-handed man of Lepanto). On Cervantes' hand, see Martin von Koppenfels, “Flauberts Hand: Strategien der 
Su bisabuelo Georg Philip Rugendas (1666-1742), fue el iniciador de la dinastía de pintores. Lo hizo por haber perdido en su juventud la mano derecha; la mutilación lo incapacitó para el oficio de relojero, que era el tradicional de su familia ... Debió aprender a usar la mano izquierda, y manejar con ella lápiz y pincel. Se especializó en la representación de batallas, y tuvo un formidable éxito derivado de la precisión sobrenatural de su dibujo ... .

(EPV 8; my emphasis)

It was Johan Moritz's great-grandfather, Georg Philip Rugendas (1666-1742) who founded the dynasty of painters. And he did so as a result of losing his right hand as a young man. The mutilation rendered him unfit for the family trade of clockmaking, in which he had been trained since childhood. He had to learn to use his left hand, and to manipulate a pencil and brush [with it]. He specialized in the depiction of battles, with excellent results, due to the preternatural [supernatural] precision of his draftsmanship ... .

(ELP 144-145)

Aira's text is thus marked by the techniques of destabilization and stabilization of a "series of assembled actions" (TdC 372; ToB 76), and the effective use of the hand is here relearned through those processes that Marcel Mauss calls "sangfroid": processes of focalization and stabilization. In this regard, here the injury of the body transforms primary cultural techniques (writing, drawing, painting) back into techniques of the body, and secondary cultural techniques (introduced by the abandoned profession of the clockmaker) become impossible. From the very beginning of the novel, the newly learned technique is connected with the concept of the "sobrenatural" (literally: "supernatural"), which means not only unnatural but superhuman. With the grandson, the text will take this aspect to the extreme.

This is the genealogical prehistory, but the injury of the great-grandson is even worse: "He was not like his ancestor, who had to start over with his left hand [literally: by educating his left hand]. If only he had been so lucky!" (ELP 181). ${ }^{52}$ His facial disfigurement burns itself "straight into his nervous system" (ELP 174), ${ }^{53}$ just as the landscape, for the "making" of which the painter first set out, ${ }^{54}$ directly burns itself onto his retina. The grotesque semantics that the text emphasizes from

Selbstimmunisierung," Poetica 34 (2002): 171-191, here 183-184; and Volker Klimpel, "Berühmte Amputierte," Würzburger medizinhistorische Mitteilungen 23 (2004): 313-327, here 314.

52 "No era como su antepasado, que había tenido que educar la mano izquierda; jojalá lo hubiera sido!” (EPV 37)

53 "lo absorbió directamente con el systema nervioso" (EPV 31).

54 “... se le abría un mundo ya hecho, y también, a la vez, por hacer, más o menos como le sucedío por la misma época al joven Darwin”; ,... the world that opened before him was roughly mapped out yet still unexplored [literally: a world already made, and also, at the same time, yet to be madel, much as it was, at around the same time, for the young Charles Darwin.” (EPV 9; ELP 146; my emphasis). 
the outset are produced by the logic that techniques of the body and cultural techniques become, in such an automatic process of branding, superfluous. However, as a medical case history the "episode" is told spatially and made observable in a reversal of the world, thereby using all the means of the grotesque to produce the spectacularity of accident and injury: carnivalesque slapstick and the horror of the Gothic novel: Frankenstein. ${ }^{55}$

On his ride of discovery, Rugendas ends up in a rock formation called "El Monigote: the puppet [on a string].” In this "circo máximo" ("vast amphitheater") of interlayered rocks, rider and horse are struck by two Frankenstein-like lightning bolts ${ }^{56}$ - "lit up with electricity, Rugendas witnessed the spectacle of his body shining" - and literally fuses to an assemblage: horse and rider together now turn a "voltereta", a somersault (this notion misses in the translation; ELP 176-174). ${ }^{57}$ The panicked animal then drags the fallen painter along, his foot in the stirrup: "a classic riding accident" (ELP 177).$^{58}$ However, the sudden appearance of a thunderstorm of apocalyptic proportions turned the sky lead-grey, scribbled a "horseshoe" across the sky ("herradura"; this notion misses in the translation; EPV 31; ELP 174) and thus anticipated a reversal of the worlds that now finally becomes manifest in the painter lying motionless with his face to the earth. His travel companions find him with a horribly disfigured face and exposed nerves (EPV 34; ELP 178). The party is forced to return to San Luis, where Rugendas suffers a medical procedure of assemblage: he is "stiched up," literally: "sewn" back together as well as possible ("lo estaban cosiendo"; EPV 35; ELP 179) - the notion of assemblage stems from the French verb assembler which can also mean "to sew together." Yet the hospital is not a place of healing but inhabited by incurable, disabled "monsters" (ELP 180). ${ }^{59}$ Rugendas thus remains

55 On the carnival, see Bakhtin, Rabelais and his World; on the Gothic novel of German Romanticism, in particular, see Kayser, The Grotesque; on slapstick see Ilka Becker, "Agencement und Amusement: Duchamp, Slapstick und retroaktive Geschichten der Moderne," in Unmenge: Wie verteilt sich Handlungsmacht?, ed. I.B., Michael Cuntz, and Astrid Kusser (Munich: Fink, 2008), 93-121.

56 As in Frankenstein, in Aira we also find two flashes of lightning in an apocalyptic thunderstorm. Mary Shelley, Frankenstein (Oxford: Oxford University Press, 2008 [1831]), 76.

57 "Volaron unos veinte metros, encendidos ... la caída no fue fatal ... sino que la magnetización del pelaje de la bestia había hecho imán, y Rugendas quedó montado en toda la voltereta ... hombre y bestia se encendieron de electricidad. Rugendas se vio brillar, espectador de sí mismo por un instante de horror" (EPV 31-32).

$\mathbf{5 8}$ "accidente que non por repetido (es un clásico de la equitación de todos los tiempos)" (EPV 33).

59 "habitado por media docena de monstruos, mitad hombre mitad animales, producto de accidentes genéticos acumulados. Ellos no tenían cura” (EPV 35). 
in his "estado semiinválido" (EPV 42; ELP 189), and the expedition is marked by spatial reversal: “The only thing that had changed was Rugendas's face. And the direction" (ELP 186). ${ }^{60}$

The text creates this "semi-invalid monster" by staging techniques of the body. Since Frankenstein (1831), the monstrous body, patched together as an assemblage of body parts, has been associated with technological inventions and electricity. ${ }^{61}$ As a result, Frankenstein's monster, especially his face, is not only repulsively ugly but also extraordinary in a frightening, grotesque way because of its nonhuman techniques of the body, which culminate in the ability to run with superhuman speed. ${ }^{62}$ By contrast, Rugendas's techniques of the body - literally: the "sleepwalking steps of a monster" (ELP 197)63 - appear exceptionally slow and stiff, disconnected from the brain, like the movements of a marionette (as in "El Monigote"), and the painter's destabilized and therefore grotesque techniques of the body transform his living space into a chaotic laboratory:

Caminaba con pasos rígidos, pero todo el cuerpo parecía afectado de inconexión ... El cuarto se había transformado, por acción de sus movimientos, en el laboratorio de un sabio loco que se proponía lograr alguna clase de transformación del mundo.

(EPV 50-51)

Rugendas walked stiffly [with stiff steps] but all the parts of his body seemed to be working loose [his whole body seemed disconnected] ... His movements had transformed the room into a mad scientist's laboratory where some transformation of the world was being hatched."

(ELP 199)

As a personal union of the monster and Frankenstein, Rugendas tries to establish a new order of his body, i.e., conexion, or in other words: the "sang-froid" claimed by Mauss that bypasses pain and drug. This first affects his habits of seeing, which are severely impaired by both. Upon documenting his first malón in the blazing sun, accompanied by his friend Krause, also a painter, Rugendas pulls a mantilla over his head, a lace cloth that fragments his gaze. Instead of experiencing a deterioration - and this is the grotesque turn - Rugendas finds that his vision even improves and, with it, the observing eye of the researcher:

60 "Lo único que había cambiado era la cara de Rugendas. Y la dirección” (EPV 40).

$\mathbf{6 1}$ This is how the "spark of being" that animated the monster through the "instruments of life" has always been read. Frankenstein (2008), 57; see also the introduction by J.K. Joseph, viii. For an exemplary overview of the vast secondary literature on Frankenstein, see the latest study on this subject by Andrew Smith: "Scientific Contexts," in The Cambridge Companion to Frankenstein, ed. A.S. (Cambridge: Cambridge University Press, 2016), 69-83.

62 See, for instance, Shelley, Frankenstein, 57-58 and 76.

63 "las evoluciones adormecidas del monstruo"; translated as "the monster's somnolent bumbling” (EPV 49; ELP 197). 
"He had never seen better in his life" (ELP 206). ${ }^{64}$ This grid of threads laid over the retina repeats the "landscape's structuring grid of horizontal and vertical lines ... overlaid by man-made traces" (ELP 155). ${ }^{65}$

Furthermore, this allusion to the cartographic, written, two-dimensional measurement of the world spatially clarifies this malón. Body and landscape fuse into a practice of measuring on paper through the staging of techniques of the body and cultural techniques:

They [Krause and Rugendas] put their papers into the saddlebags and spurred the horses on ... . It seemed they would have to resign themselves to seing the Indians in miniature, like lead soldiers. Yet the details were all there, violently impressed on their retinas, magnified [literally: amplified] on the paper [1]....

It was like wandering from room to room at a party, from the living room to the dining room, from the bedroom to the library, from the laundry to the balcony, all full of noisy, happy, more or less drunk guests, looking for a place to cuddle or trying to find the host to ask him for more beer. Except that it was a house without doors or windows or walls, made of air and distance and echoes, of colors and landforms.

This stream could have been the bathroom. The Indians wanted to charge but they were retreating; the white men wanted to retreat, but in order to do so they had to charge (in order to scare the enemy more effectively with their bangs). This ambivalence was driving the horses crazy; they plunged into the water, splashed about, or simply stopped to drink, very calmly, while their riders yelled themselves hoarse in simultaneous flight and pursuit. The skirmish had an infinite (or at least algebraic) plasticity, and since Rugendas was observing it at closer range this time, his flying pencil traced [literally: he threw/catapulted his pencil at/ toward] details of tense and lax muscles, wet hair clinging to supremely expressive shoulders [2] ... Everything sketched in this explosive present was material for future compositions, but although it was all provisional, a constraint came into play. It was as if each volume captured in two dimensions on the paper would have to be joined up with the others, in the calm of the studio, edge to edge, like a puzzle, without leaving any gaps. And that was indeed how it would be, for the magic of drawing [3] turns everything into a volume, even air. Except that for Rugendas the "calm of the studio" was a thing of the past; now there was only torment, drugs and hallucinations.

The savages scattered in all directions, and four or five came climbing up the knoll where the painters had stationed themselves. Krause drew his revolver and fired twice into the air; Rugendas was so absorbed that his only reaction was to write BANG BANG on his sheet of paper [4]. (ELP 206-209; my emphasis) ${ }^{66}$

64 "Nunca había visto mejor" (EPV 55).

65 "Al cuadriculado de verticales y horizontales que componía el pasaje se superponía el factor humano, también reticular" (EPV 16).

66 (EPV 56-58). [1] "los detalles estaban hahí, hacían una violenta impresión en sus retinas y se amplificaban en el papel” (EPV 56). [2] "lanzaba el lápiz en escorzos de musculatura distendida y contraída, cabelleras mojadas pegándose a hombros sumamente expresivos ...” (Spanish lanzar, to throw, to catapult; EPV 58). [3] "la magia del debujo" (EPV 58). [4] "Rugendas estaba tan compenetrado que se limitó a escribir en su hoja: BANG BANG” (EPV 58). 
The chaos of the large-scale raid carried out by an "Indian" tribe in the barely developed area in order to steal animals from local farmers is, in being compared to a party in a bourgeois living room, linguistically tamed in a grotesque way, made representable in the first place. The "wandering" from room to room (with Certeau: practicing the map) ${ }^{67}$ produces, in a grotesque reversal, a wild ride for the purpose of documenting through drawing. Closely related to this are the themes of fragmentation. The "Indian" bodies transferred into the two-dimensionality of paper as fragments by the manual techniques of the artist (the stock of paper is carried in saddlebags and is as mobile as the painters riding on horseback) spring directly from the maimed painter's body. It is the fragmented view caused by the injury that permits an exclusively fragmented perception of the "Indian" body, which also appears as such on paper. The logic here is that these fragments could be put together at home in the studio like a puzzle into a whole. Rugendas's injury, however, has made this impossible; for him, this fragmented chaos has become permanent. And in this context, the representability of this chaos proves equally impossible on both the textual and narrative levels: it is marked by a number of referential short circuits, as - to use Aria's language - inconexión between the signifier and the signified. The main character thereby infects the text. For example, the comparison of the malón with a stroll through a house with neither walls nor doors nor windows literally disappears into thin air.

The climax of the novel is marked by a scaling and dimensioning staged by the techniques of an intoxicated body that is both riding and drawing, namely, as the painter depicts the raging "Indians" with his pencil, at first from a great distance and then at close range. The riding warriors, who first appear as "lead soldiers," are depicted in their athletic physicality; the brush itself becomes a piece of war equipment and acquires a stubborn power to act in its detachment from the body, when Rugendas literally "throws" his pencil at the "Indian" body to capture the spectacle of its muscles.

Since the impressions now inscribe themselves directly into Rugendas's retina and the techniques of the painter's maimed body are characterized by a grotesque inconexion that extends into the drawing pencil, what is seen comes to paper as if by magic, as if run through an amplifier, or through a technical apparatus (Spanish: amplificar). The man struck by lightning is now apparently able to leap forward over seventy years of art history: after the realistic, meticulous style of his drawing before the injury, he leaves behind a work that is almost surrealist in its scale and content. This transformation culminates in a Dadaist-like writing

67 "ir recorriendo los ambientes de una casa" (EPV 57). Michel de Certeau, Arts de faire: The Practice of Everyday Life, trans. Steven Rendall (Berkeley: University of California Press, 1984). 
scene, with a pencil replacing the depiction of the malon with all its agents and components by the registration of its sounds, captured in a doubling of four capital letters: BANG BANG.

The impression of a surrealist "picturesque" 68 écriture automatique is produced by a staging of techniques of the body that, at the end and as the climax of the case history, no longer appear here at all. The pencil has taken on a life of its own. Rugendas's accident was much worse than that of his ancestor, who had to laboriously train his left hand, and yet Rugendas not only no longer needs to practice any techniques of the body: he no longer needs any hands at all. The spectacle of the cultural technique of writing is based on a technique of the body that is no longer present. This absence culminates in the claimed invention of the avant-garde per se, literally avant la lettre: Impressionism, Expressionism, Surrealism, and Dadaism together, from the machine to the paper. The "nonhuman" cultural technique of the monstrous painter Rugendas corresponds, in this respect, to the superhuman technique of the body of Shelly's raging monster: "The body is a strange thing, and when it is caught up in an accident involving nonhuman forces, there is no predicting the result" (ELP 179). ${ }^{69}$

The result of my thoughts, starting with Mauss's lecture "Les Techniques du Corps" up to this reading of a literary text, could be summarized as follows: I have read both Mauss's lecture and Aria's novel as case histories to show that techniques of the body, as is presumably true for all cultural techniques, constitutively depend on storytelling. This is because they are obviously generally based on an individual case and an associated case study. Both are constitutively characterized by an anthropological, or more pointedly: by a more or less personal, biographical core, which can be analytically generalized and abstracted to a scientific exploration and documentation as (with Pethes) "measuring new fields of knowledge."

The dilemma of media studies to whether (to quote Harun Maye) "the techniques of the body can be subsumed under cultural techniques or, vice versa, cultural techniques can be derived from the techniques of the body" could be answered from the perspective developed here: it depends. For here we are not dealing with a logic of either/or, but first of all with a question of focalizing: techniques of the body are essentially cultural techniques; cultural techniques

68 "La escena era sumamente pintoresca. El carboncillo empezó a volar sobre el papel." (“The scene was picturesque in extrem [the scene of the malón in de Argentinian landscape, as well as the following scene of drawing]. The stick of charcoal began to fly across the paper”; EPV 56; ELP 207).

69 "El cuerpo es una cosa extraña, y cuando lo afecta un accidente donde actúan fuerzas no humanas, nunca se sabe cuál será el resultado” (EPV 34-35). 
are techniques of the body if the focus is not on the question of differentiation but rather if the analytical spotlight is directed toward the body itself. ${ }^{70}$ With the discussion of habitualized cultural techniques or techniques of the body, the question of focusing is then followed by the question of concrete processes of stabilization and destabilization of such techniques, which can clearly be analyzed in many different ways. Mauss' examples of the steamship and of "sang-froid," which at first glance seem so completely different, come together in the allusion to the "trained" body as an ostensibly technical, "cold-blooded" object, whose production (i.e., stabilization as such), as shown by Mauss's Alpinism series and also his example of swimming, requires, however, significant processual efforts of habituation or dehabituation.

Harun Maye's dilemma, however, has even greater implications, because this question necessarily entails discussing a fundamental understanding of media:

\begin{abstract}
Should cultural techniques be understood primarily as a physically habitualized skill, possibly supported by tools and instruments that then appear as an extension of these techniques of the body? or are they primarily media techniques that, derived from dominant basic media (writing, image, number), constantly generate new media and cultural innovations? ${ }^{71}$
\end{abstract}

In Aira's Episodio, cultural techniques are finally not supported by an instrument and thus become an extension or exteriorization of techniques of the body, as the body is separated from its instrument (of writing, drawing, arithmetic) in a magical act (inconexión). The instrument becomes autonomous, as if by magic. In this respect, the text introduces the question of precisely this connection, as Maye poses it here, taking it to an absurd conclusion. First, as a stubborn resistance of such tools and instruments (in other words: the agency of objects). And second, as a conjunction of techniques of the body and cultural techniques, which are discussed as manual techniques or rather: as techniques of handedness. With the concept of the "result," the effectiveness of both and thus their connection to the medium remains unknown. The sheet of paper on which the drawing and writing take place remains a mass of fragments that cannot be assembled into a meaningful whole. Nothing remains of these so-called basic media in their Dadaist sequence (BANG BANG) but symbolic onomatopoeia.

So what is the conclusion to draw from all of this? With its main character, the text comprehends the immortality of art as manual techniques inherent to human

70 Mauss speaks of the body not as an "instrument," but as "man's first and most natural technical object, and at the same time technical means"; "Le corps est ... plus exactement, sans parler d'instrument, le premier et le plus naturel objet technique, et en même temps moyen technique, de l'homme" (TdC 372; ToB 75).

71 Maye, "Was ist eine Kulturtechnik," 122. 
beings. But at its ending, it stages a scene of the Anthropocene, the beginning of which is marked by the zero hour of midnight. The question of techniques of the body and cultural techniques has been settled inasmuch as the body becomes a machine.

In this context, the text constructs an argument via the idea of algebraic lines, thus abstracting Rugendas's initial route to measure the unknown pampas. For the injured painter, as one reads in the text, there would only be a perpetual beginning in the sense of starting from scratch, symbolized namely by the broken line, the inconexión, just as Rugendas's accident forced him to turn back on his journey from San Luis to Buenos Aires. His friend, the painter Krause, on the other hand, "by virtue of his health, was moving along an unbroken line, a continuum, without beginning or end" (ELP 225) ${ }^{72}$ : Because of his injury - and "this last part of the episode is even more inexplicable then the rest" - Rugendas thus thinks about his approaching death at the end of the novel (ELP 226). ${ }^{73}$ In his imagination, all humankind dies out after his fragments, which indeed cannot be put together like a puzzle, and make the long journey to Europe by sea, where they end up in galleries on the wall.

They [the Indians] might have killed him. A minor detail. In any case, by the time his correspondents saw the resulting pictures, that is by the time his work reached European galleries or museums, he would certainly be dead. The artist, as artist, could always be already dead. There was something absurd about trying to preserve his life. An accident, big or small, could kill a man, or a thousand, or a thousand million men at once. If night were lethal, we would all die shortly after sunset. Rugendas might have thought, as people often do: "I have lived long enough," especially after what had happened to him. Since art is eternal, nothing is lost.

(EPV 71-72; ELP 226-227)

Ultimately, the ending of the story does not emphasize the eternity of the medium but the perpetuated manual technique, which has here become posthuman. Rugendas sits drawing by the campfire:

[E]staba tan concentrado en los dibujos que no se daba cuenta de nada. Drogado por el dibujo y el opio, en la medinoche salvaje, efectuaba la contigüidad como un automatismo más. El procedimiento seguía actuando por él.

(EPV 74)

$[\mathrm{H}] \mathrm{e}$ was so absorbed in his work that he remained oblivious to the rest. In the depths of that savage night, intoxicated by drawing and opium, he was establishing contact [literally: contiguity] as if it were simply another reflex. The procedure went on operating through him.

(ELP 229-230)

72 "Era Krause, no él, quien por efecto de la salud estaba en una línea única, un continuo, sin comienzo ni fin" (EPV 70).

73 "Esta parte final del episodio fue más inexplicable todavía que el resto" (EPV 71). 
The fragmentation (and abstraction) of the body (as Rugendas imagines it in drawing the "Indians") is historically linked to the synchronization of the body with the machine. Although the working hand lost importance, the concept of artistic creativity developed as a reaction. ${ }^{74}$ The "automatismo más," presented here as the coronation of the artist at the end of the novel, consists in making the connection (conexión; contigüidad) that was impossible for the human body to accomplish with its manual techniques. These no longer play a role. The body becomes the machine of el arte por el arte (l'art pour l'art). ${ }^{75}$

Already for the observer Mauss, and in how he reproduces them (narratively), techniques of the body are spectacular. This spectacularity is not only grounded in the visual. With his anecdote about the soldiers' gait to marching music, Mauss captures the spectacle of techniques of the body as both an observable and an audible phenomenon, just as Aira makes the techniques of the body, as a writing scene, visible and audible, and with them the connection between techniques of the body and cultural techniques. "BANG BANG." The end of Aira's novel once again makes it clear that a technique of the body, especially in its "medial compressions," "76 not only is a narrative but also depends on narration. Cinema (as in Mauss) as well as literary texts can be optimal experimental arrangements to discuss techniques of the body and their spaces (and ultimately their mediality).

74 This was a process that is widely considered to have been triggered by the industrial age that emerged in the nineteenth century. See Becker, "Agencement und Amusement: Duchamp, Slapstick und retroaktive Geschichten der Moderne,” 121.

75 See Bernhard Siegert, “Türen: Zur Materialität des Symbolischen," Zeitschrift für Medien- und Kulturforschung 1, 1 (2010): Kulturtechnik: 151-170.

76 Schüttpelz, "Körpertechniken," 114. 
